\title{
KOMPETENSI KEWIRAUSAHAAN DENGAN KEBERHASILAN USAHA PETERNAK SAPI PERAH PUJON, MALANG
}

\author{
Pamela $^{1}$, Rachmat Pambudy ${ }^{2}$, dan Ratna Winandi ${ }^{2}$ \\ 1)Program Studi Budidaya Tanaman Pangan Politeknik Tonggak Equator, Pontianak, Kalimantan Barat \\ 2)Staf Pengajar Departemen Agribisnis, Fakultas Ekonomi dan Manajemen, Institut Pertanian Bogor \\ e-mail : ${ }^{1)}$ situmorangpamela@gmail.com
}

\begin{abstract}
Pujon, Malang is the largest milk producer in East Java. Nevertheless, the productivity and farm size are at low level. It indicates that entrepreneurial competencies of dairy farmers at poor level. This research presents the results from depth interview with 105 dairy farmers in Malang Regency, East Java. Based on this information, it can be concluded that entrepreneurial competencies of respondents are at low level on strategic skills, and middle level on leadership and technical management skills, Entrepreneurial competencies are generated positively by personal orientation (interest of dairy farmers in group activities, and risk taking behavior, and demographic characteristic (working experience). It has a positive relationship to successful business. Interest of dairy farmers in group activites improvement could up grade the personal orientation, entrepreneurial competencies, and successful business.
\end{abstract}

Keywords: entrepreneurial competencies, dairy farmer, malang.

\section{PENDAHULUAN}

\section{LATAR BELAKANG}

Wirausaha merupakan aset suatu bangsa untuk dapat mendukung pertumbuhan ekonomi negara. Wirausaha bertindak sebagai agen perubahan, membawa ide-ide untuk pasar dan merangsang pertumbuhan karena adanya kecenderungan untuk berinovasi. Inovasi memegang prinsip keterbaruan yang diharapkan akan membantu meningkatkan pertumbuhan ekonomi suatu negara (Casson et al. 2006). Inovasi lokal merupakan inovasi yang akan meningkatkan partisipasi sosial dan pendapatan ( Hall, et al. 2012)

Provinsi Jawa Timur merupakan salah satu sentra peternakan sapi perah di Indonesia (Direktorat Jenderal Peternakan dan Kesehatan Hewan Kementerian Pertanian, 2011) dengan kontribusi sebesar 52 persen ${ }^{3}$, dan Kabupaten Malang merupakan penghasil susu sapi terbesar di Jawa Timur".

Produsen susu terbesar di Kabupaten Malang yaitu Kecamatan Pujon (Pemerintah
Kabupaten Malang Dinas Peternakan dan Kesehatan Hewan, 2010). Produktivitas peternak sapi perah di kecamatan Pujon pada tahun 2011 yaitu sekitar 1,5 kiloliter per tahun (Koperasi Peternakan dan Pemerahan Air Susu Sapi Rakyat SAE Pujon, 2012). Nilai tersebut berada dibawah produktivitas nasional yaitu tiga kiloliter per tahun (Setiadi dan Sobahi, 2008).

Rata-rata kepemilikan sapi laktasi di Pujon pun rendah yaitu tiga ekor per peternak (Koperasi Peternakan dan Pemerahan Air Susu Sapi Rakyat SAE Pujon, 2012). Nilai tersebut masih di bawah kriteria kepemilikan sapi laktasi yang dapat mencapai kelayakan usaha secara ekonomi yaitu 7 ekor per peternak (Setiadi dan Sobahi, 2008).

Produktivitas dan kepemilikan sapi laktasi yang rendah dapat membuat suatu dugaan bahwa kompetensi kewirausahaan peternak sapi perah di Pujon rendah. Pertanyaan penelitian yang menarik untuk dikaji adalah bagaimana kompetensi kewirausahaan peternak sapi perah?.

\footnotetext{
3 Bappeda Jawa Timur. Jatim Berkontribusi Terhadap Susu Nasional Sebesar 52 Persen.

http:/ / bappeda.jatimprov.go.id/2013/02/04/jatim-berkontribusi-terhadap-produksi-susu-nasional-sebesar-52persen.html [6 Maret 2013]

4 Disnak Jatim.Statistik Produksi.disnak.jatimprov.go.id/web/statistik_produksi_detail.php[6 Maret 2013]
} 
Kompetensi kewirausahaan dapat dipengaruhi oleh tiga hal. Ketiga hal tersebut yaitu (1)lingkungan usaha (Bloodgood et al. 1995), (2) orientasi individu (Hofstede, 1991), (3) karakteristik individu (Chamorro, 2005). Bagaimana hubungan lingkungan usaha, orientasi individu, dan karakteristik individu terhadap kompetensi kewirausahaan peternak sapi perah di Kecamatan Pujon?

Kompetensi kewirausahaan selanjutnya akan mempengaruhi secara langsung tingkat keberhasilan usaha (Bird, 1995). Pendapatan peternak berkorelasi positif dengan kepemilikan sapi perah (Setiadi dan Sobahi, 2008). Salah satu indikator keberhasilan wirausaha adalah produktivitas, dan pendapatan (Bird, 1995) Dengan demikian indikator keberhasilan peternak sebagai wirausahawan dapat dilihat dari produktivitas dan kepemilikan jumlah sapi perah.Bagaimanakah hubungan dari kompetensi kewirausahaan terhadap keberhasilan wirausaha peternak?

Berdasarkan pemaparan tersebut, dapat dibuat suatu rumusan tujuan penelitian, yaitu menganalisis (1) kompetensi kewirausahan peternak (2) hubungan lingkungan usaha, orientasi individu, dan karakteristik individu dengan kompetensi kewirausahaan (3) hubungan kompetensi kewirausahaan dengan keberhasilan usaha.

\section{METODE PENELITIAN}

Lokasi penelitian yaitu Desa Pandesari, Kecamatan Pujon, Kabupaten Malang, Provinsi Jawa Timur. Pemilihan desa ini didasarkan wawancara dengan pihak koperasi SAE Pujon, bahwa Desa Pandesari relatif baik kualitas susunya. . Ruang lingkup penelitian ini adalah kompetensi kewirausahaan peternak sapi perah.

Pengambilan sampel dilakukan secara convenience sampling, dengan kelompok peternak yang dirujuk oleh Koperasi SAE Pujon. Responden diwawancarai langsung dengan menggunakan kuesioner. Jumlah responden yaitu 105 orang.

Analisis deskriptif dengan menggunakan skala likert untuk menentukan kompetensi kewirausahaan. Dalam menganalisis hubungan antar variabel, digunakan metode Structural Equation Model (SEM).

Variabel-variabel yang digunakan dalam penelitian ini dapat dilihat pada Tabel 1.

Skala likert yang digunakan dalam penelitian ini terbagi menjadi tiga skala. Skala likert digunakan untuk mengetahui tingkat kompetensi kewirausahaan peternak. Skala pertama yaitu "Tahu". Skala kedua yaitu "Melaksanakan". Skala ketiga yaitu "Mahir". Semakin tinggi skala likert berarti semakin tinggi tingkat kompetensi peternak.

\section{Tabel 1. Variabel Penelitian}

\begin{tabular}{|c|c|c|}
\hline No. & Variabel Laten & Variabel Indikator \\
\hline 1. & Lingkungan Usaha (Y1) & $\begin{array}{l}\text { (1) Persaingan (X1) } \\
\text { (2) Kedinamisan (X2) }\end{array}$ \\
\hline 2. & Orientasi Individu (Y2) & $\begin{array}{l}\text { (1) Sikap terhadap kelompok peternak (X3) } \\
\text { (2) Sikap terhadap resiko }(X 4)\end{array}$ \\
\hline 3. & Karakteristik Individu (Y3) & $\begin{array}{l}\text { (1) Usia ketika memasuki wirausaha }(X 5) \\
\text { (2) Pendidikan }(X 6) \\
\text { (3) Pengalaman Kerja (X7) } \\
\text { (4) Pelatihan (X8) }\end{array}$ \\
\hline 4. & Kompetensi Kewirausahaan (Y4) & $\begin{array}{l}\text { (1) Strategik (X9) } \\
\text { (2) Manajemen Teknis (X10) } \\
\text { (3) Kepemimpinan (X11) }\end{array}$ \\
\hline 5. & Keberhasilan Usaha (Y5) & $\begin{array}{l}\text { (1) Produktivitas (X12) } \\
\text { (2) Jumlah Kepemilikan Sapi Laktasi (X13) }\end{array}$ \\
\hline
\end{tabular}


Hubungan antar variabel, serta model struktural dan model pengukurannya digambarkan dalam bentuk diagram lintas (path diagram) pada Gambar 1.

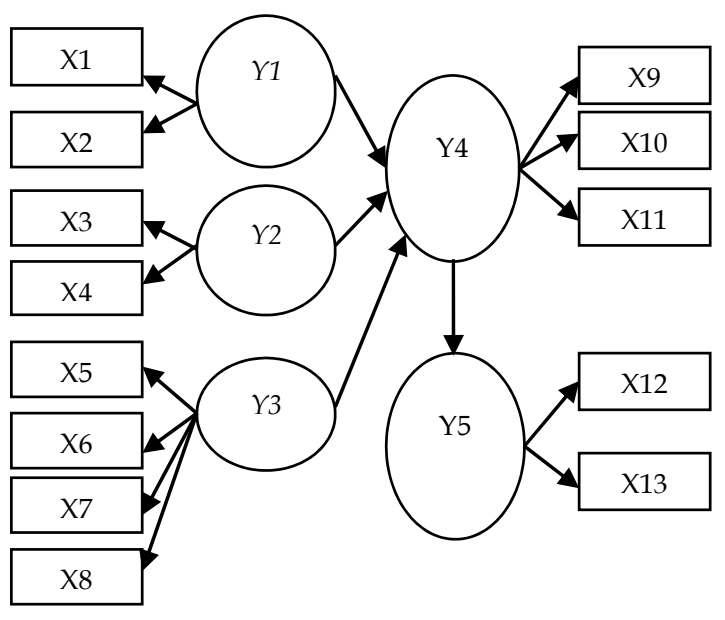

Gambar 1. Diagram Lintas SEM

Kompetensi rendah atau tahu menggambarkan bahwa peternak tidak melakukan aktivitas yang ditanyakan dalam kuesioner. Kompetensi sedang atau laksanakan menggambarkan bahwa peternak melakukan aktivitas yang ditanyakan dalam kuesioner, namun belum mahir. Kompetensi tinggi atau mahir menggambarkan bahwa peternak dinilai sudah mahir melakukan aktivitas yang ditanyakan dalam kuesioner. Skala pengukuran kompetensi dapat dilihat pada Tabel 2.

Tabel 2. Skala Pengukuran Kompetensi

\begin{tabular}{|l|c|}
\hline \multicolumn{1}{|c|}{ Uraian } & Nilai \\
\hline $\begin{array}{l}\text { Kompetensi Rendah } \\
\text { (Tahu) }\end{array}$ & $1,00-1,69$ \\
$\begin{array}{l}\text { Kompetensi Sedang } \\
\text { (Laksanakan) }\end{array}$ & $1,70-2,39$ \\
$\begin{array}{l}\text { Kompetensi Tinggi } \\
\text { (Mahir) }\end{array}$ & $2,40-3,00$ \\
\hline
\end{tabular}

\section{HASIL DAN PEMBAHASAN}

\section{LINGKUNGAN USAHA MENURUT PETERNAK}

Gambaran umum lingkungan usaha menurut peternak akan diceritakan ke dalam dua sub pembahasan, yaitu gambaran umum persaingan usaha, dan gambaran umum kedinamisan dalam kegiatan usaha. Persaingan usaha menurut peternak dapat diceritakan berdasarkan dua hal, yaitu (1) kemudahan di dalam menebak kegiatan peternak lainnya dalam meningkatkan penjualan, dan (2) pengaruh perubahan teknologi dalam kualitas hasil. Persaingan usaha digambarkan oleh mudah atau tidaknya menebak perilaku peternak lainnya dalam berwirausaha, dan kedinamisan dalam kegiatan usaha digambarkan oleh stabil atau fluktuatif harga susu yang diterima peternak.

Sebagian besar (55.24 persen) peternak responden berpendapat bahwa relatif mudah menebak tindakan peternak lainnya dalam berwirausaha, dan sisanya yaitu 44.76 persen peternak responden menjawab tidak tahu apakah tindakan peternak lainnya dalam meningkatkan penjualan dapat ditebak dengan mudah atau tidak. Dengan demikian tindakan peternak relatif mudah ditebak dalam meningkatkan penjualan.

Sebanyak 88,57 persen peternak responden menjawab bahwa perubahan teknologi sangat mempengaruhi akan kualitas hasil, 8,57 persen peternak responden menjawab tidak tahu apakah perubahan teknologi mempengaruhi kualitas hasil atau tidak, dan sisanya yaitu sebanyak 2,86 responden menjawab bahwa perubahan teknologi tidak mempengaruhi kualitas hasil. Dengan demikian sebagian besar peternak responden mempersepsikan bahwa perubahan teknologi sangat mempengaruhi kualitas hasil.

Berdasarkan pemaparan tersebut dapat disimpulkan bahwa persaingan usaha menurut peternak relatif kecil, hal tersebut dikarenakan tindakan peternak lainnya dapat dengan mudah ditebak dalam meningkatkan penjualan. Salah satu langkah yang dapat dilakukan untuk meningkatkan penjualan yaitu dengan merubah teknologi.

Perubahan teknologi dapat dilakukan antara lain perbaikan kualitas semen inseminasi buatan, perbaikan mutu konsentrat, dan regenerasi sapi laktasi. Namun perubahan teknologi dipersepsikan oleh peternak responden tidak membawa pada perubahan manfaat yang relatif besar. Hal 
tersebut dikarenakan kenaikan harga input, sedangkan harga output relatif tetap.

Gambaran umum kedinamisan dalam kegiatan usaha yang dilakukan peternak dapat diceritakan berdasarkan stabil atau fluktuasi harga susu yang diterima oleh peternak. Sebanyak 73,33 persen peternak menjawab bahwa harga susus stabil, dan sisanya yaitu 26,67 persen menjawab tidak tahu. Dengan demikian sebagian besar peternak responden mempersepsikan bahwa kedinamisan usaha yang dihadapi relatif kecil atau cenderung stabil.

\section{ORIENTASI INDIVIDU PETERNAK}

Pada sub bab ini akan dibahas mengenai orientasi individu peternak yang dapat dilihat dari dua hal. Hal pertamayaitu sikap terhadap kelompok peternak, dan yang kedua yaitu peternak terhadap resiko.

Pemaparan pertama yaitu sikap terhadap kelompok peternak. Sebanyak 62 persen peternak responden memiliki sikap menyukai kebersamaan yang dilakukan di dalam kelompok peternak, dan sisanya yaitu sebanyak 38 persen peternak responden memiliki sikap kurang menyukai kebersamaan yang dilakukan dalam kelompok peternak.

\section{KARAKTERISTIK INDIVIDU PETERNAK}

Rentang usia peternak responden yaitu 20 - 80 tahun. Rata-rata usia peternak yaitu sekitar 45 tahun. Sebagian besar peternak berada dalam usia produktif ( 16-64 tahun). Sebanyak 84 persen pendidikan peternak di bawah SMA, 15 persen pendidikan peternak di tingkat SMA, dan satu persen pendidikan peternak di tingkat sarjana. Dengan demikian tingkat pendidikan peternak responden relatif rendah.

Sebanyak 27 persen peternak responden memasuki dunia wirausaha ketika berusia di bawah 20 tahun, dan 30 persen peternak memasuki dunia wirausaha ketika berusia 2025 tahun. Sebanyak 17 persen peternak memasuki dunia wirausaha pada usia 26-30 tahun, dan sisanya yaitu sebanyak 26 persen memasuki dunia wirausaha ketika berusia lebih dari 30 tahun. Dengan demikian, sebagian besar peternak responden memasuki dunia wirausaha ketika berada di usia yang relatif muda.

Sebagian besar (55 persen) peternak bekerja di luar sektor peternakan sebelum memutuskan menjadi wirausaha. Pekerjaan yang dikerjakan oleh peternak responden sebelum memutuskan menjadi wirausaha, sebagian besar yaitu bertani. Di sisi lain, sebanyak 33 persen peternak responden yang pernah bekerja di sektor peternakan merupakan peternak yang mewarisi usaha peternakan sapi perah warisan dari orangtuanya. Selanjutnya, sebanyak 12 persen peternak responden mengaku tidak mengaku tidak memiliki pekerjaan sebelumnya, antara lain ibu rumah tangga.

Durasi waktu dari peternak responden bekerja sampai memutuskan untuk memulai usaha peternakan sapi perah dapat digambarkan sebagai berikut. Sebanyak 80 persen peternak responden memiliki pengalaman 010 tahun, dan sisanya yaitu 20 persen peternak responden pernah bekerja lebih dari 10 tahun. Dengan demikian, sebagian besar peternak responden merupakan tenaga kerja terampil sebelum memutuskan untuk memulai wirausaha.

Sebagian besar (89,5 persen) peternak tidak menerima pelatihan usaha. Meskipun demikian, 89.5 persen peternak responden tersebut mengaku mendapatkan pembelajaran mengenai pengusahaan sapi perah dari orangtua atau belajar secara otodidak.

Sebanyak 90.5 persen peternak responden menjelaskan bahwa mereka tidak menerima pelatihan usaha, baik itu di sektor peternakan ataupun di sektor lainnya. Dengan demikian, sebagian besar (90.5 persen) peternak responden tidak mening-katkan kemampuan dirinya melalui pelatihan.

\section{KOMPETENSI KEWIRAUSAHAAN PETERNAK RESPONDEN}

Kompetensi kewirausahaan peternak responden terbagi dalam tiga aspek yaitu kompetensi bidang strategik, teknis, dan 
kepemimpinan. Rata-rata skor kompetensi untuk masing-masing bidang dapat dilihat pada Tabel 3.

Tabel 3. Nilai Bidang Kompetensi

\begin{tabular}{|l|c|c|}
\hline \multicolumn{1}{|c|}{ Uraian } & Nilai & $\begin{array}{c}\text { Tingkatan } \\
\text { Kompetensi }\end{array}$ \\
\hline $\begin{array}{l}\text { Kompetensi bidang } \\
\text { strategik }\end{array}$ & 1,64 & Rendah \\
$\begin{array}{l}\text { Kompetensi bidang } \\
\text { teknis }\end{array}$ & 1,98 & Sedang \\
\hline $\begin{array}{l}\text { Kompetensi bidang } \\
\text { kepemimpinan } \\
\text { Rata-Rata }\end{array}$ & 1,96 & Sedang \\
\hline
\end{tabular}

Berdasarkan Tabel 3 kompetensi bidang strategik peternak responden berada dalam tingkat rendah. Hal tersebut dapat dilihat antara lain dari sikap peternak responden yang pada umumnya tidak mencari tahu produk olahan susu dan tidak mengembangkan usaha sapi perahnya ke dalam produk olahan. Peternak responden relatif tidak mengembangkan usaha sapi perahnya ke dalam produk olahan dikarenakan sebagian besar peternak responden menjual produk susu kepada Koperasi dan relatif tidak ada pelatihan dari Koperasi untuk mengembangkan usaha sapi perahnya ke dalam produk olahan. Kompetensi bidang teknis peternak responden berada dalam tingkat sedang. Hal tersebut dapat dilihat dari manajemen kandang yang baik. Peternak responden relatif mampu memerah susu sesuai dengan contoh penyuluh, mengetahui kemana akan memperbaiki alat teknis, dan menjaga kebersihan kandang. Peternak responden relatif lemah dalam manajemen keuangan dalam pengusahaan sapi perah. Hal tersebut terlihat dari relatif tidak dibuatnya pencatatan keuangan harian, atau bulanan peternak responden. Kompetensi kepemimpinan peternak responden berada dalam tingkat sedang. Hal tersebut dapat dilihat dari peternak responden memiliki hubungan kekeluargaan yang baik, dan dapat memotivasi lingkungan sekitarnya.

Secara umum atau rata-rata, skor kompetensi kewirausahaan peternak responden berada dalam tingkat sedang. Hal tersebut berarti kompetensi kewirausahaan peternak responden masih perlu ditingkatkan, khususnya kompetensi dalam bidang strategik

\section{PRODUKTIVITAS DAN JUMLAH KEPEMILIKAN SAPI LAKTASI}

Komposisi peternak sapi perah menurut tingkat produktivitas digunakan untuk mengetahui hasil dari kegiatan usaha yang dilakukan oleh peternak sebagai wirausaha. Rata-rata produktivitas peternak yaitu sebesar 10,78 L / ekor / hari. Rentang produktivitas yaitu 7-18 L / ekor / hari. Simpangan baku sebesar 2.93. Simpangan baku yang tinggi menggambarkan bahwa usia sapi yang dimiliki oleh peternak relatif heterogen.

Komposisi peternak responden menurut jumlah kepemilikan sapi laktasi digunakan untuk mengetahui skala usaha yang dilakukan oleh peternak sebagai wirausaha. Sebanyak 73 persen peternak berada dalam skala usaha kecil (kepemilikan sapi laktasi satu sampai tiga ekor), 20 persen peternak berada dalam skala usaha menengah (kepemilikan sapi laktasi empat sampai enam ekor), dan tujuh persen peternak berada dalam skala usaha besar (kepemilikan sapi laktasi minimal tujuh ekor).

\section{ANALISIS STRUCTURAL EQUATION MODEL AWAL}

Hasil SEM yang telah diestimasi dalam hasil estimasi berupa muatan faktor dan $\mathrm{T}$ Hitung dapat dilihat pada Tabel 4 .

Berdasarkan Tabel 4, maka variabel indikator yang valid yaitu X2, X3, X4, X7, X9, X10, X11, dan X13. Selanjutnya model awal tersebut direspesifikasi dengan tidak mengikutsertakan variabel yang tidak valid. Hasil muatan faktor variabel dan T-Hitung pada model respesifikasi seperti pada Tabel 5 .

Variabel X2, X3, X4,X7, X9, X10, X11, dan X13 selanjutnya dilakukan uji reliabilitas. Variabel dikatakan reliable jika construct reliability $(C R)>0,6$ dan variance extracted $(\mathrm{VE})>0,4$. Hasil uji realibilitas variabel $\mathrm{X} 2, \mathrm{X}$, 
Tabel 4. Nilai Muatan Faktor Variabel dan T Hitung Variabel Indikator Model Awal

\begin{tabular}{|l|c|c|c|c|}
\hline \multicolumn{1}{|c|}{ Variabel laten } & Variabel indikator & Muatan faktor & T-hitung & Keterangan \\
\hline Lingkungan Usaha (Y1) & X1 & 0,32 & 3,08 & Tidak valid \\
\hline \multirow{3}{*}{ Orientasi Individu (Y2) } & X2 & 1,00 & 13,54 & Valid \\
\hline & X3 & 0,67 & 7,59 & Valid \\
\hline Karakteristik Individu & X4 & 0,67 & 7,61 & Valid \\
\hline (Y3) & X5 & 0,52 & 5,59 & Tidak valid \\
\hline & X6 & $-0,22$ & $-2,58$ & Tidak valid \\
\hline Kompetensi & X7 & 0,89 & 6,36 & Valid \\
\hline Kewirausahaan (Y3) & X8 & $-0,53$ & $-5,43$ & Tidak valid \\
\hline \multirow{2}{*}{ Keberhasilan Usaha } & X9 & 0,88 & 6,95 & Valid \\
\hline & X10 & 0,86 & 8,96 & Valid \\
\hline
\end{tabular}

Tabel 5. Nilai Muatan Faktor Variabel dan T-hitung Variabel Indikator Model Respesifikasi

\begin{tabular}{|l|c|c|c|c|}
\hline \multicolumn{1}{|c|}{ Variabel laten } & $\begin{array}{c}\text { Variabel } \\
\text { indikator }\end{array}$ & Muatan faktor & T-hitung & Keterangan \\
\hline Lingkungan Usaha (Y1) & X2 & 1,00 & 14,13 & Valid \\
\hline Orientasi Individu (Y2) & X3 & 0,67 & 8,09 & Valid \\
\hline Karakteristik Individu (Y3) & X4 & 0,67 & 7,79 & Valid \\
\hline Kompetensi Kewirausahaan & X7 & 1,00 & 14,43 & Valid \\
\hline (Y3) & X10 & 0,87 & 6,69 & Valid \\
\hline Keberhasilan Usaha & X11 & 0,84 & 7,78 & Valid \\
\hline
\end{tabular}

X4,X7, X9, X10, X11, dan X13 dapat dilihat pada Tabel 6. Berdasarkan Tabel 6, X2, X3, X4,X7, X9, X10, X11, dan X13 reliable.

Model respesifikasi selanjutnya akan diperiksa tingkat kecocokan keseluruhan model agar dapat diperoleh kesimpulan apakah model dapat diterima atau tidak. Berdasarkan uji kecocokan keseluruhan model, model yang respesifikasi dapat diterima dan kemudian dapat diintrepretasikan.

Tabel 6. Nilai CR dan VE Model Respesifikasi

\begin{tabular}{|l|c|c|c|c|c|c|}
\hline \multicolumn{1}{|c|}{ Uraian } & $\begin{array}{c}\text { Muatan } \\
\text { faktor }\end{array}$ & $\begin{array}{c}\text { Muatan } \\
\text { faktor }\end{array}$ & Error & $\begin{array}{c}\text { Jumlah } \\
\text { muatan } \\
\text { faktor }\end{array}$ & $\begin{array}{c}\text { Construct } \\
\text { reliability (CR) }\end{array}$ & $\begin{array}{c}\text { Variance } \\
\text { extracted (VE) }\end{array}$ \\
\hline X2 & 1,00 & 1,00 & 0,00 & 0,00 & 1,00 & 1,00 \\
\hline Jumlah & 1,00 & 1,00 & 0,00 & & & \\
\hline X3 & 0,67 & 0,45 & 0,55 & 1,80 & 0,62 & \\
\hline X4 & 0,67 & 0,45 & 0,55 & & & \\
\hline Jumlah & 1,34 & 0,90 & 1,10 & & 1,00 & \\
\hline X7 & 1,00 & 1,00 & 0,00 & 0,00 & & \\
\hline Jumlah & 1,00 & 1,00 & 0,00 & & 0,91 & \\
\hline X9 & 0,87 & 0,76 & 0,24 & 6,86 & & \\
\hline X10 & 0,84 & 0,71 & 0,30 & & & \\
\hline X11 & 0,91 & 0,83 & 0,17 & & & \\
\hline Jumlah & 2,62 & 2,30 & 0,71 & & 0,99 & \\
\hline X13 & 1,00 & 1,00 & 0,01 & 1,00 & & 0,99 \\
\hline Jumlah & 1,00 & 1,00 & 0,01 & & & \\
\hline
\end{tabular}


Hasil uji kecocokan keseluruhan model resifikasi dapat dilihat pada Tabel 7.

Tabel 7. Uji Kecocokan Keseluruhan Model Resifikasi

\begin{tabular}{|c|c|c|}
\hline Uraian & Hasil & Keterangan \\
\hline $\begin{array}{l}\text { Significance } \\
\text { Probability (P-value) }\end{array}$ & 0,96 & Close Fit \\
\hline $\begin{array}{l}\text { Root Mean Square } \\
\text { Residual }\end{array}$ & 0,03 & Good Fit \\
\hline $\begin{array}{l}\text { Root Mean square } \\
\text { Error of } \\
\text { Approximation }\end{array}$ & 0,00 & Close Fit \\
\hline Goodness of Fit & 1,00 & Good Fit \\
\hline $\begin{array}{l}\text { Adjusted Goodness of } \\
\text { Fit Index }\end{array}$ & 0,99 & Good Fit \\
\hline $\begin{array}{l}\text { Comparative Fit } \\
\text { Index }\end{array}$ & 1,00 & Good Fit \\
\hline Normed Fit Index & 0,99 & Good Fit \\
\hline
\end{tabular}

Lingkungan usaha (Y1) direfleksikan oleh satu variabel indikator yaitu kedinamisan (X2). Berdasarkan Tabel 5, nilai muatan faktor kedinamisan bertanda positif. Tanda positif menggambarkan bahwa semakin dinamis lingkungan bisnis yang dihadapi peternak, semakin mendukung peternak dalam mengembangkan usaha peternakan yang dikelola.

Orientasi individu (Y2) direfleksikan oleh dua variabel indikator yaitu sikap terhadap kelompok peternak (X3) dan sikap terhadap resiko (X4). Berdasarkan Tabel 5, nilai muatan sikap terhadap kelompok peternak dan sikap terhadap resiko bertanda positif dalam merefleksikan orientasi individu peternak responden dalam mengambil keputusan bisnis yang dilakukannya. Nilai positif pada muatan faktor variabel kelompok peternak dan sikap terhadap resiko menggambarkan bahwa semakin peternak responden menyukai kegiatan dengan kelompok peternak, dan semakin memperhitungkan resiko maka semakin tinggi orientasi individu peternak untuk menjalankan usahanya.

Karakteristik individu (Y3) direfleksikan oleh satu variabel yaitu pengalaman kerja (X7). Berdasarkan Tabel 5, nilai muatan faktor pengalaman kerja bertanda positif. Hal tersebut berarti bahwa semakin lama pengalaman kerja yang dimiliki oleh peternak sebelum memutuskan menjadi wirausaha peternak, dan semakin banyaknya pengalaman kerja di luar sektor peternakan semakin baik karakteristik individu dalam hal keanekaragaman pengetahuan, pengalaman, dan luasan relasi.

Kompetensi kewirausahaan (Y4) direfleksikan oleh tiga variabel indikator yaitu strategik (X9), manajemen teknis (X10), dan kepemimpinan (X11), Berdasarkan Tabel 5, nilai muatan faktor pada variabel indikator strategik, manajemen teknis, dan kepemimpinan bertanda positif. Dengan demikian, semakin tinggi kemampuan strategik, manajemen teknis, dan kepemimpinan yang dimiliki oleh peternak, semakin tinggi kompetensi kewirausahaan.

Keberhasilan kewirausahaan direfleksikan oleh satu variabel indikator yaitu jumlah kepemilikan sapi laktasi (X13). Berdasarkan Tabel 5, nilai muatan faktor pada variabel jumlah kepemilikan sapi laktasi bertanda positif. Dengan demikian, semakin tinggi jumlah kepemilikan sapi laktasi, semakin tinggi pula tingkat keberhasilan usaha peternak.

\section{HUBUNGAN LINGKUNGAN USAHA, ORIENTASI INDIVIDU, DAN KARAKTERISTIK INDIVIDU DENGAN KOMPETENSI KEWIRAUSAHAAN.}

Hubungan yang dijelaskan pada sub bab ini adalah hubungan lingkungan usaha, orientasi individu, dan demografi dengan kompetensi kewiraushaan, Hubungan tersebut dapat dilihat berdasarkan nilai muatan faktor pada Tabel 8 .

\begin{tabular}{|c|c|c|c|}
\hline \multicolumn{4}{|c|}{$\begin{array}{l}\text { Tabel 8. Nilai Muatan } \\
\text { Variabel Laten }\end{array}$} \\
\hline Hubungan & $\begin{array}{c}\text { Muatan } \\
\text { Faktor }\end{array}$ & $\begin{array}{c}\text { T- } \\
\text { Hitung }\end{array}$ & Keterangan \\
\hline Y1 & $-0,07$ & $-0,91$ & $\begin{array}{c}\text { Tidak } \\
\text { signifikan }\end{array}$ \\
\hline $\mathrm{Y} 2 \div$ & & 7,51 & Signifikan \\
\hline & $-0,21$ & $-2,42$ & Signifikan \\
\hline $\mathrm{Y} 4 \rightarrow \mathrm{Y} 5$ & 0,79 & 7,63 & Signifikan \\
\hline
\end{tabular}


Berdasarkan Tabel 8, variabel lingkungan usaha (Y1) secara independen tidak berpengaruh signifikan terhadap kompetensi kewirausahaan (Y4). Hal tersebut dikarenakan kondisi lingkungan usaha yang relatif tidak dinamis. Selanjutnya Kompetensi kewirausahaan (Y4) peternak sapi perah dipengaruhi signifikan oleh orientasi individu (Y2) dan karakteristik individu (Y3).

Variabel orientasi individu lebih mempengaruhi kompetensi kewirausahaan bila dibandingkan dengan karakteristik individu. Hal tersebut terlihat dari nilai muatan faktor orientasi individu lebih besar dari nilai muatan faktor karakteristik individu.

Orientasi individu berpengaruh positif terhadap kompetensi kewirausahaan. Dengan demikian, semakin tinggi minat individu terhadap kegiatan kelompok peternak, dan semakin memperhitungkan resiko, maka kompetensi kewirausahaan peternak semakin tinggi.

Karakteristik individu berpengaruh negatif terhadap kompetensi kewirausahaan. Dengan demikian, semakin lama pengalaman kerja yang dimiliki oleh peternak, dan semakin pengalaman kerja tersebut di luar sektor peternakan, semakin rendah kompetensi kewirausahaan. Hal tersebut mengindikasikan bahwa pengalaman pekerjaan di sektor peternakan dibutuhkan sebelum menjalankan usaha peternakan sapi perah. Di sisi lain, semakin singkat menjadi seorang pekerja, justru semakin tinggi kompetensi kewirausahaan peternak. Hal tersebut dikarenakan semakin lama menjadi seorang pekerja, ada kecenderungan semakin takut dalam mengambil resiko.

\section{HUBUNGAN KOMPETENSI KEWIRAUSAHAAN DENGAN KEBERHASILAN USAHA}

Kompetensi kewirausahaan berpengaruh positif dan signifikan terhadap keberhasilan usaha (Tabel 8). Semakin tinggi kompetensi kewirausahaan semakin tinggi keberhasilan usaha. Dengan demikian, semakin tinggi kompetensi kewirausahaan baik di bidang strategik, teknis, maupun kepemimpinan, semakin tinggi keberhasilan usaha (direfleksikan dengan kepemilikan sapi laktasi).

\section{KESIMPULAN}

Adapun kesimpulan dari hasil penelitian ini yaitu :

1. Kompetensi kewirausahaan peternak sapi perah di Kecamatan Pujon, Kabupaten Malang berada dalam tingkat yang rendah untuk aspek strategik, dan sedang untuk aspek kepemimpinan dan manajemen teknis..

2. Lingkungan usaha tidak berpengaruh secara signifikan dengan kompetensi kewirausahaan. Orientasi individu dan karakteristik individu memiliki pengaruh yang signifikan terhadap kompetensi kewirausahaan. Orientasi individu merupakan variabel yang paling berpengaruh terhadap kompetensi kewirausahaan.

3. Kompetensi kewirausahaan memiliki pengaruh yang signifikan dan positif terhadap keberhasilan usaha.

\section{UCAPAN TERIMA KASIH}

Penulis mengucapkan terima kasih kepada Biro Perencanaan dan Kerjasama Luar Negeri (BPKLN) Kementerian Pendidikan dan Kebudayaan Republik Indonesia yang telah memberikan Beasiswa Unggulan kepada penulis selama menyelesaikan pendidikan S2 di Program Studi Magister Sains Agribisnis, Institut Pertanian Bogor.

\section{DAFTAR PUSTAKA}

Bird, B. 1995. Toward a Theory of Entrepereneurial Competency. Connecticut (US) : Jai Press

Bloodgood, JM, Spienza HJ, Carsrud AL. 19995. The Dynamics of New Business Start-ups. Connecticut (US): Jai Press 
Casson M, B Yeung, A Basu, N Wideson.2006.

. The Oxford Handbook of Entrepreneurship. New York (US): Oxford University Press.

Chamorro, TP. 2005. Personality and Intellectual Competence. New Jersey (US). Lawrence Erlbaum Associates

Direktorat Jenderal Peternakan dan Kesehatan Hewan. 2011. Statistik Peternakan dan Kesehatan Hewan 2011. Jakarta (ID) : Direktorat Jenderal Peternakan dan Kesehatan Hewan. Kementerian Pertanian RI

Hall, J, S Matos, L Sheehan, B Silvestre. Entrepreneurship and Innovation at the Base of the Pyramid : A Recipe for Inclusive Growth or Social Exclusion? Journal of Management Studies. Oxford (GB) dan Malden (US) : Blackwell Publishing

Hofstede, G. 1991. Cultures and Organizations : Software of the mind. New York (US) : Mc-Graw Hill.

Koperasi Peternakan dan Pemerahan Air Susu Sapi Rakyat SAE Pujon. 2012.Laporan Tahunan Tahun 2011. Malang (ID) : Koperasi Peternakan dan Pemerahan Air Susu Sapi Rakyat SAE Pujon.

Pemerintah Kabupaten Malang Dinas Peternakan dan Kesehatan Hewan. 2010. Laporan Tahunan 2009. Malang (ID) : Pemerintah Kabupaten Malang Dinas Peternakan dan Kesehatan Hewan

Setiadi, D, Ramdan Sobahi. 2008. Model Industri Peternakan Sapi Perah Rakyat : Suatu Gagasan Pola 100-1000-10000. Di dalam : Prospek Industri Sapi Perah Menuju Perdagangan Bebas 2020. Prosiding Semiloka Nasional; Jakarta, 21 April 2008. Jakarta (ID). Pusat Penelitian dan Pengembangan Peternakan Bekerjasama dengan Sekolah Tinggi Ilmu Ekonomi Keuangan dan Perbankan Indonesia: (576-585) 
